\title{
Sizes of Genomes of Paleoproterozoic Microfossil Eukaryotes
}

\author{
Anatoly M Belyaev ${ }^{1 *}$ and Paul V Yukhalin ${ }^{2}$ \\ ${ }^{1}$ Institute of Earth sciences, St. Petersburg State University, Russia \\ ${ }^{2}$ Sidose LLC, St. Petersburg, Russia
}

*Corresponding author: Anatoly M Belyaev, Institute of Earth sciences, St. Petersburg State University, Russia, Tel: 89213294356; Email: abel-7-777@yandex.ru; a.beliaev@spbu.ru

\section{Investigation Paper}

Volume 4 Issue 1

Received Date: December 10, 2020

Published Date: January 20, 2021

DOI: $10.23880 /$ ijpbp-16000121

\section{Abstract}

We studied siliceous rocks (microquartzites) enriched with light isotope ${ }^{12} \mathrm{C}$ of biogenic origin ( $\delta^{13} \mathrm{C}$ up to $-29.5 \%$ ), found within the volcanogenic-sedimentary strata of the Paleoproterozoic (1640 Ma) of Hogland Island in the Gulf of Finland (Baltic Sea). In these siliceous rocks we found silificated and ferruginizated microfossils of planktonic eukaryotes: amoebas, diatoms, foraminifers, flagellates, virus-like and multicellular organisms. In mineralized cytoplasm and nuclei of microfossils we found grains of apatite, which could be crystallized from phosphoric acid residue of decayed nucleotides. This allowed as to estimate the size of genomes of ancient eukaryotes and virus-like structures, which were tens of thousands of times greater than those of genomes of modern single-cell organisms. Additionally, we estimated the weights of genomes of ancient eukaryotes using the principle of genomic-nuclear proportionality: that the molecular weights of genomes are proportional to the size of the nuclei. The weights of genomes of microfossil eukaryotes: flagellates, foraminifers, and virus-like structures, estimated by the inclusions of apatite grains and by the size of the nuclei, averaged tens of thousands picogram and, consequently, could contain tens of thousands billion pairs of nucleotides. Presumably, the giant genomes of ancient eukaryotes consisted predominantly of non-coding sequences, that served as a reserve that ensures the vital activity of cells when exposed to streams of mutagens from the environment. One of the mutagenic factors could be significant radioactivity, both background and intracellular, caused by high concentrations of radioactive ${ }^{40} \mathrm{~K}$ isotope in seawater. The favorable ecological and geochemical environment and the abundance of biophilic elements (especially phosphates) in the waters of the inland basin could play the role of an evolutionary springboard in the history of biosphere evolution.

Keywords: Siliceous Rocks; Carbon Isotopes; Paleoproterozoic Microfossils; Eukaryotes; Viruses; Genomes

Abbreviations: BP: Basalt Pillow; MK: Microquartzites; RP: Rhyolites Pillow; PB: Pyroclastic Breccia; SS: Sericite Slate; PY: Protoflagellates Yukhalina; DH: Dinovirus Hoglandi.

\section{Introduction}

The unity of the biological world implies the presence of certain organic compounds, i.e. nucleoside phosphates of ATP, RNA, and DNA, in all living organisms. It is assumed that ancient microorganisms also had to contain nucleotides. Some researchers believe that the genomes of eukaryotes gradually grew in size and complexity during the evolutionary process, partially due to lateral transgenic transfer by viruses [1-3]. However, so far there was no material evidence of that in the paleontological record. This is because skeletonless singlecell organisms experience postmortem transformations lysis (dissolution) or collapse. Nevertheless, certain natural environments created favorable conditions for fossilization of microorganisms, where eukaryotic microfossils could retain mineral pseudomorphoses of organelles: nuclei, flagella, vacuoles, mitochondria and membranes. It became possible in case of rapid mineralization of microorganisms when they were still alive, before postmortem transformations. The microorganisms without mineral skeleton are preserved best in chemogenic-sedimentary siliceous rocks formed in thermal springs as a result of precipitation of silicon oxide from hot silicic acid-rich waters. During silicification the organelles of microorganisms are displaced with silica 


\section{International Journal of Paleobiology \& Paleontology}

oxides. Studies of silicification of cyanobacteria near existing thermal springs, as well as experimental studies, showed that these processes occurred within several hours, almost during the lifetime of microorganisms [4-6]. Additionally, large masses of chemogenic-sedimentary siliceous rocks could form due to underwater volcanism, as a result of interaction of melted magmatic material with seawater. Such siliceous rocks (microquartzites) with microfossils of the most ancient eukaryotes were identified within the volcanogenic-sedimentary strata of Paleoproterozoic Hogland formation, outcropping on Hogland Island in the Gulf of Finland (RUSSIA) [1].

\section{Geological Setting of the Hogland Island}

Hogland Island is located in the Gulf of Finland (Baltic Sea) on the southern margin of Baltic shield and Wiborg rapakivi granite batholith (WB) (Figure. 1.1). The rocks of Svecofennian basement: metamorphic gneisses and amphibolites, orogenic gabbrodiorites (1950-1850 Ma), post-orogenic granites and pegmatites (1800-1750 Ma) are overlain by the subhorizontal strata of Hogland lithostratigraphic formation, presented by quartz conglomerate (thickness $0-20 \mathrm{~m})$, basalts $(0-40 \mathrm{~m})$ and rhyolites (up to $110 \mathrm{~m}$ ) (Figures 1.2; 1.3).
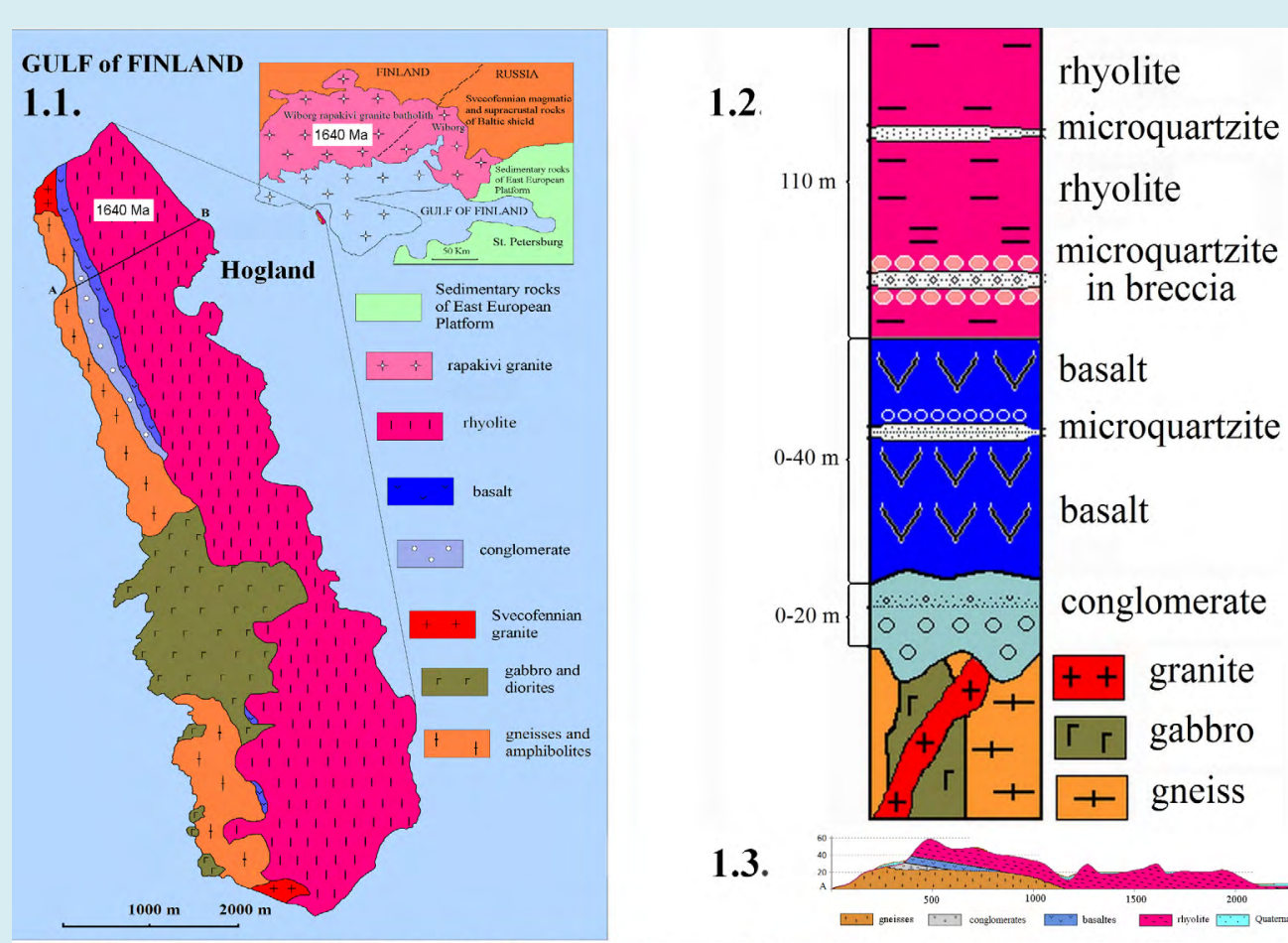

1.3.
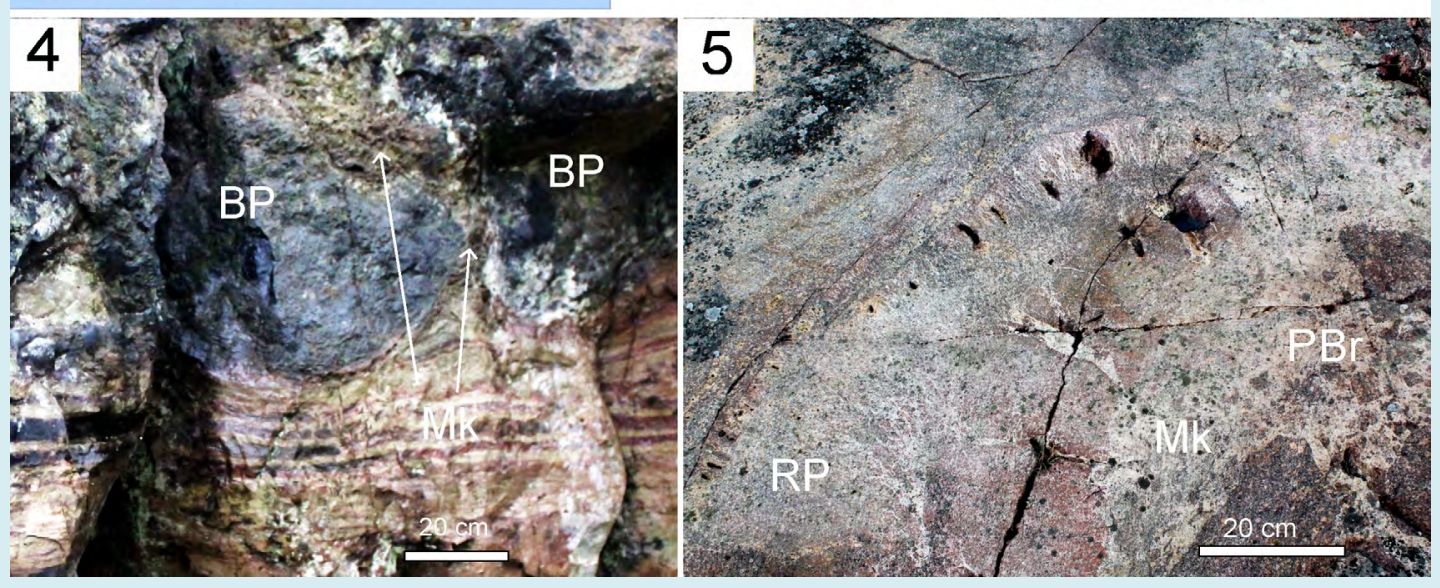

Figure 1: Geology and rocks of Hogland Island. 1.1. Schematic geologic map of Hogland Island. 1.2. Stratigraphic chart of Hogland formation; 1.3. Schematicgeologic section of the Hogland Island along line A-B; 1.4. Basalt pillow (BP) laves overlapping strata of banded microquartzites (Mk). Outcrop; 1.5. Rhyolites pillow (RP) laves are traversed by zone of pyroclastic breccia (PBr) is cemented by microquartzites (Mk) and sericite slate (SS). Outcrop. 


\section{International Journal of Paleobiology \& Paleontology}

Isotope and geochemical data show that Hogland rhyolites and basalts are volcanic counterparts of granites and basic rocks, Wiborg plutonic rapakivi dated $1640 \mathrm{Ma}$. U-Pb dating of zircons from the granite porphyries of the volcanic rocks gave upper intercept age 1638+/-4 Ma and 1640+/$11 \mathrm{Ma}[7,8]$ and confirmed relations between rhyolites and rapakivi granites. Volcanic rocks successions were formed by underwater eruptions in a continental basin, which is evidenced by pillow structures in the laves - typical for such environments [8,9]. Additionally, there is geochemical evidence that the juvenile fluids, extracted from alkaline basaltic and rapakivi granite magmas during eruptions, significantly enriched the seawater with potassium $[1,9]$.
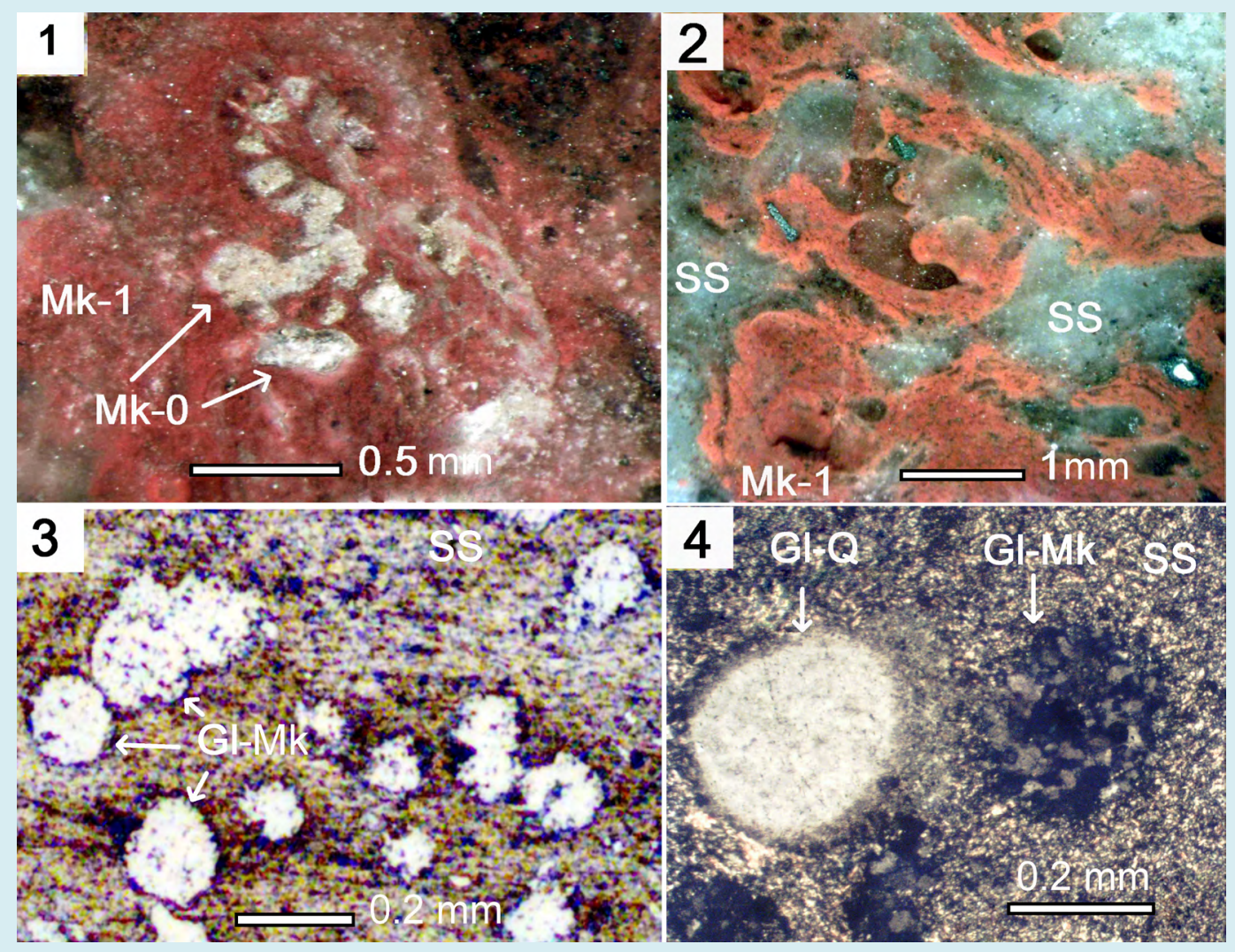

Figures 2: Microquartzites and sericite slate (SS) in the cement of pyroclastic breccia in rhyolites. 2.1. Microquartzites (Mk_1) on the silificated mucous substance of biofilms surrounding the cyanobacterium trichome (Mk_0). Polished specimen; 2.2 . Fragments (Mk_1) with fibrous-trickle texture in the sericite shale SS. Polished specimen; 2.3. Sericite slate (SS) with inclusions of the rounded globules-sands. Thin section, without analyzer; 2.4. Sericite slate (SS) with inclusions of the rounded globules of quartz and microquartzites. Thin section, with analyzer.

The siliceous rocks formed as a result of interaction of melted magmatic material with seawater, and they are present in lava strata in the form of interlayers and lenses, as well as in the cement of eruptive breccias among the covers of basalts and rhyolites. The effusive hot magma heated the near-bottom water to high temperatures, leading to intense dissolution of silica oxides on the surface of the flows. The mineralized waters heated by lava rose to the upper horizons of the marine basin and rapidly cooled, and amorphous silica particles formed and settled in the dips of palaeotopography over solidified basalt and rhyolite lavas. The siliceous rocks also often bordered pillow structures (Figure 1.5). In the rhyolite lavas the siliceous rocks occur both as thin lenses, and in the cement of eruptive breccias. During contact metamorphism they were transformed into microquartzites, which formed in siliceous sediments of various generations (Mk), by silicification of the mucosal substance of biofilms (Mk_1), and planktonic microorganisms (Mk_0). The microquartzites (Mk_1) in the cement of eruptive breccias exhibit striated wavy structure, with interweaved pink and 


\section{International Journal of Paleobiology \& Paleontology}

gray bands often enveloping microfossils of cyanobacteria and eukaryotes. For examples, the microquartzites formed by silicification of biofilms (Mk_1), envelop a curved structure resembling a cyanobacterial trichoma Mk_0. (Figure 2.1). The microquartzites are closely associated with sericite slates (SS), which consists of small sub-parallel flakes of sericite mica (Figure 2.2). They formed during metamorphism of hydromica of shale sediments. Both microquartzites and sericite slate contain foreign inclusions, globules (Gl) up to $0.5 \mathrm{~mm}$ in size, presented by rounded particles of microquartzites and quartz grains (Figures $2.3 ; 2.4$ ).

Most likely, the globules were small rounded sand grains, introduced into marine sediments as a result of wind transfer by sandstorms [1]. The presence of globules from rocks of different genesis in the microquartzites and the sericite aggregate cementing breccias' from rhyolites indicates their sedimentary origin. The heat from the overlaying lava flows resulted in contact metamorphism of the sediments, and they were transformed into striated microquartzites, consisting of fine quartz crystals, and sericite slates, consisting of finegrained sericite mica [1,2].

\section{Results and Interpretation}

Isotope composition studies of carbon from graphite contained in the microquartzites showed that it is enriched with light isotope ${ }^{12} \mathrm{C}\left(\delta^{13} \mathrm{C}=-27.1--29.5 \%\right.$ ) (Table 4). This, apparently, is caused by the presence of the detritus of planktonic microorganisms in the siliceous rocks [1].

Microscopic studies of microquartzites from interlayers in basalts and rhyolites identified numerous remains of silicified and ferruginizated microfossils of prokaryotes and eukaryotes, similar in morphology to modern and fossil coccoid and spiral cyanobacteria, amoebas, diatoms, foraminifera, flagellates and multicellular organisms, previously unknown in the rocks of Paleoproterozoic age $[1,2]$.

It is important to note that the microfossils found are substitution pseudomorphs that were formed simultaneously with volcanic rocks 1640 million years ago. Judging by the well- preserved outlines, internal structure and mutual location of the microfossils in microquartzites and sericite slates, their fossilization (silification and ferruginization) occurred simultaneously with fossilization of the surrounding mucosal substance (biofilm). This makes it possible to study the spatial relationships of ancient microorganisms in the ecosystem of plankton communities, besides the well-preserved features of the internal structure.

\section{Conditions of Fossilization of Planktonic Communities of Microorganisms}

Formation of chemogenic-sedimentary siliceous rocks in the environment of underwater eruptions was accompanied by the processes of fossilization of planktonic communities of microorganisms. The waters heated by lava and saturated with iron ions and silicon oxides, rose into the near-surface horizons of the marine basin and led to rapid fossilization (silicification and ferruginization) of planktonic communities of microorganisms, together with the mucosal substance where they coexisted. Silicon oxides from the mineralized solution penetrated the microorganisms and replaced the cytoplasm and organelles with a colloidal gel of silicic acid or opal, while iron hydroxides were deposited on the walls of membranes and partitions, or formed a colloidal gel replacing the cytoplasm. Fragments of mineralized bacterial films together with microfossils of planktonic microorganisms settled to the bottom and sank into siliceous and clay sediments.

\section{Morphology and Mineral Composition of Certain Eukaryote Microfossils}

Microfossils similar in morphology to modern flagellates, foraminifera, multicellular structures, and giant viruses were found in the cement of eruptive breccias in rhyolites, microquartzites, and sericite shales [1].

Protoflagellates Yukhalina:Microfossils Protoflagellates yukhalina (PY) were found in sericite shales together with foreign inclusions - rounded globules and grains of microquartzites [1] (Figure 3).

PY exhibits pseudomorphoses of flagella, composed of chains of hematite grains, all encapsulated in microquartzites (Mk-0) with hematite inclusions, formed when the cell mucosa was replaced. The cytoplasm of the cell is replaced by quartz-hematite aggregate with specific symplectic structure of fusion of two mineral phases, formed as a result of simultaneous crystallization of siliceous gel and iron hydroxides (Figures 3.1; 3.2). Between the mineralized cytoplasm and the siliceous shell, there were probably digestive vacuoles replaced by hematite - Hem (DV). Inside the PY contours, rounded formations resembling the core $(\mathrm{N})$ and contractile vacuoles - Hem (CV) are visible, composed of hematite. The quartz-hematite aggregate contains a grain of apatite (Ap). 


\section{International Journal of Paleobiology \& Paleontology}

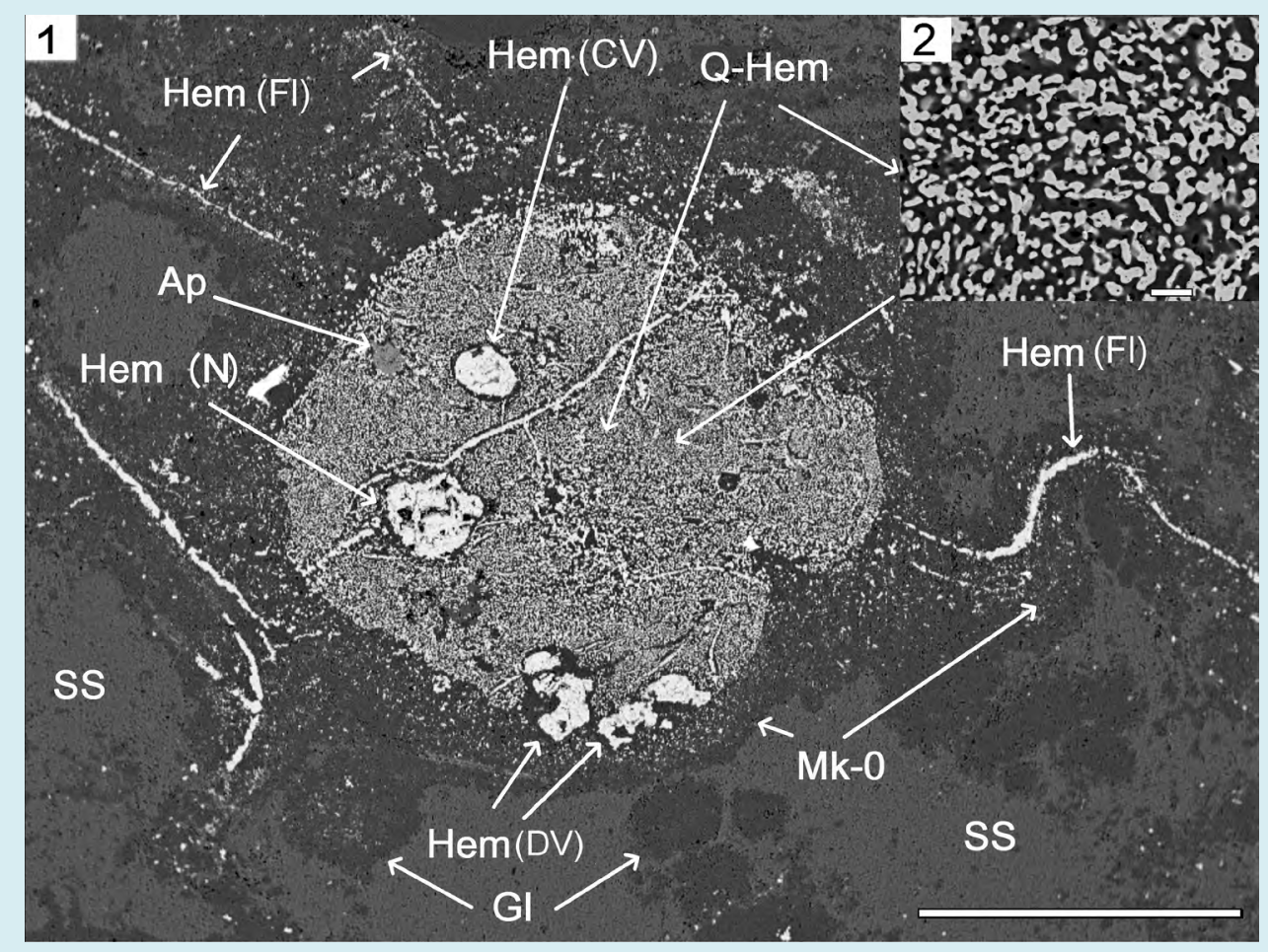

Figure 3: Microphoto of the Protoflagellates yukhalina structures in the sericite slate from cement of breccias in rhyolites under scanning electron microscope JSM-6510LA with energy- dispersion spectrometer JED-2200. 3.1. Protoflagellates yukhalina structures: Sericite slate - SS (grey) with inclusions of the rounded globules Gl (dark grey)of microquartzites, microquartzites Mk-0 (dark grey) formed during silification of cell mucous membrane, quartz-hematite aggregate Q-Hem (Q-dark grey, Hem-light grey) replacing the cell's cytoplasm, hematite-replaced flagella Hem (Fl) (light grey), nucleus Hem (N) (light grey), hematite-replaced contractile vacuoles Hem (CV) (light grey), hematite-replaced digestive vacuoles Hem (DV) (light grey), Apatite - Ap; 3.2. Quartz-hematite aggregate with symplectic texture of intergrowth of two mineral phases: quartz (dark grey) and hematite (light grey). Polished section. With analyzer. Scale ruler $-0.1 \mathrm{~mm}$.

\section{Foraminifera-Like Structures in the Microquartzites}

Foraminifera microfossils were known earlier only in the rocks of Neoproterozoic and Cambrian [10]. Microfossils with morphology similar to foraminifera are found in the Sericite Slate (SS) from cement of breccias in rhyolites. Pink microquartzites (Mk-1) with patchy striated structure were formed as the result of silification of mucous substance, where the cells of planktonic communities coexisted [1,2].

Microquartzites Mk-1 contain inclusions of quartz grains (Q) and rounded "bubble" structures composed of microquartzites (Mk-0), which may have been formed during the silification of the cytoplasm of ancient prokaryotes of planktonic microorganisms. The foraminifera-like microfossils are oval/rounded-shaped, size $1 \times 1.5 \mathrm{~mm}$, in places; they are surrounded by thin edges of MK-0 microquartzites, formed when the cell mucosa was replaced. Inside the contours of foraminifera microfossils are composed of gray Mk-0, which was formed, possibly, during cytoplasm silification. At the edge of the cell, chains of rare hematite grains are visible, possibly formed when the outer membrane of the cell was replaced, the chains consist of small hematite grains. One of the microfossils of foraminifera-like structures (Fo-2) contains an elongated prismatic apatite grain (Figure. 4.1;4.3). In the central parts of foraminiferalike structures Fo-4 we observed partitions and rounded zoned nucleus-like object, composed of hematite and quartz grains (Figure. 4.2), stemming several linear formations composed of chains of hematite grains formed during the replacement of intracellular membranes. 


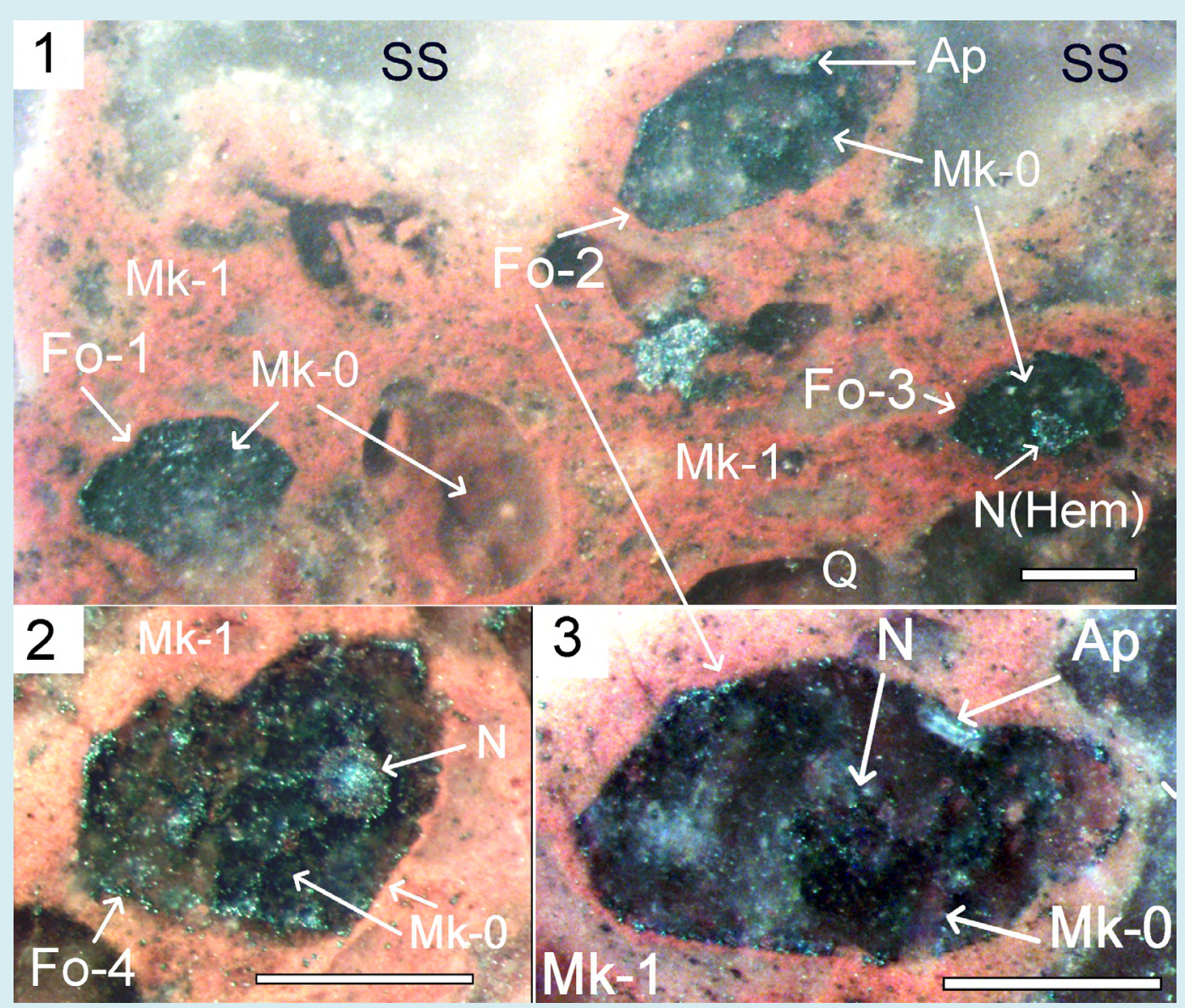

Figure 4: Microfossils of foraminifera-like structures in microquartzites. Polished section. Scale $0.5 \mathrm{~mm}$. 4.1. Foraminiferalike structure (Fo) in microquartzites (Mk-1) and sericite slate (SS), composed of Mk-0 and grains of hematite. Inside the contours, a rounded zonal nucleus-like structure (N) is composed of hematite (Hem). Moving away from the core of the fibrous formations made up of chains of hematite grains; 4.2. Foraminifera-like structure (Fo-4) in microquartzite (Mk-1), composed Mk-0 and grains of hematite. Inside the contours, a rounded zonal nucleus-like structure is composed of hematite and quartzhematite aggregate (Q-Hem); 4.3. Foraminifera-like structure (Fo-2) in microquartzite (Mk-1), is composed Mk-0 and grains of hematite. Inside the contours, a rounded unclear nucleus-like structure is composed of hematite grain. There's a grain of Apatite (Ap) on the edge.

\section{Microfossils of the Virus-Like Structures in the Sericite Slate}

For the first time several varieties of hexagonal or pentagonal microfossils of virus-like structures, of various size and internal structure, with various mineral composition pseudomorphs, were found in microquartzites and sericite shales with silicified and ferruginizated microfossils of flagellates and foraminifers. Morphologically, they are similar to some species of giant viruses from the family Mimiviridae with icosahedral capsids [11]. Hexagonal fragments of microfossils (pseudomorphoses over protein shell residues) are observed in direct contact with microfossils of amoeboid structures or with hexagonal cells, encapsulated together in siliceous membranes (Figure. 5.1.).

However, the fossil structures exceed the linear dimensions of modern giant viruses thousand times or more. In addition, virus-like microfossils have signs of division, and nuclei and vacuoles typical for eukaryots, while viruses, by definition, are formations with no cellular structure, capable of reproduction only in the cells of living organisms. Therefore, the identified microfossils are considered viruslike in a group of unclear systematic position (Incertae sedis). 


\section{International Journal of Paleobiology \& Paleontology}

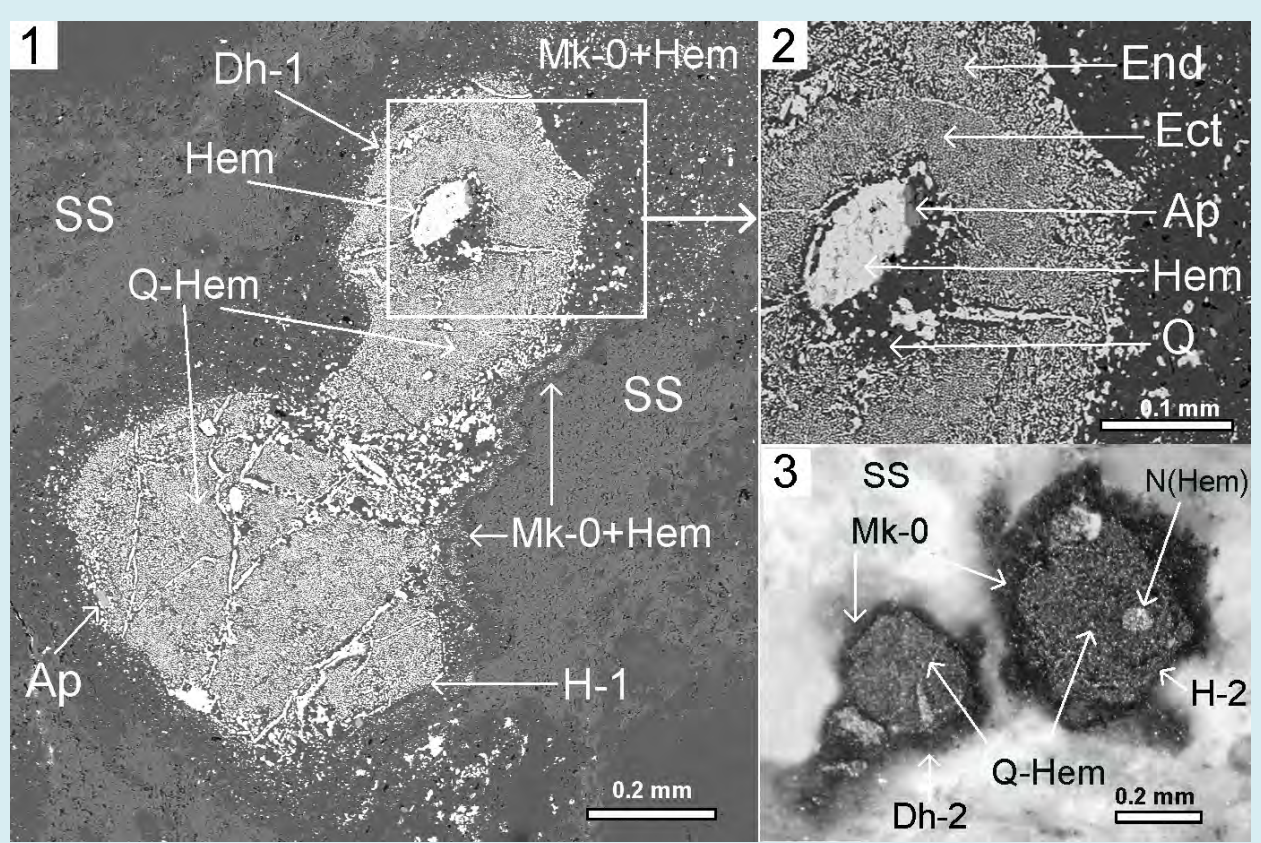

Figure 5: Microfossils of the virus-like structures of the Dinovirus hoglandi in the sericite slate (SS), 5.1-5.2 - under scanning electron microscope JSM-6510LA with energy-dispersion spectrometer JED-2200. 5.1. Structure Dinovirus hoglandi (D.h.1) in "contact" with the hexagon- cell structure (H-1): Sericite Slate - SS (grey), microquartzites globules - Gl (dark grey), microquartzites - Mk-0 (dark grey), formed during replacement of mucous membrane cells, quartz-hematite aggregate Q-Hem (Q-dark grey, Hem-light grey) with symplectic texture, replacing the cell's cytoplasm, nucleus - N(Hem) (light grey), hematite contractile vacuoles - Hem (CV) (light grey), digestive vacuoles - Hem (DV) (light grey), Apatite - Ap; 5.2. Fragment of D.h.-1 head. Quartz-hematite aggregate with symplectic texture of intergrowth of two mineral phases: Q-dark grey, and Hem-light grey; 5.3. Structure Dinovirus hoglandi (D.h.-2) in "contact" with the hexagon-cell structure H-2: Sericite Slate - SS (grey), microquartzites - Mk-0 (dark grey), formed during replacement of mucous membrane cells, quartz-hematite aggregate - Q-Hem (Q- dark grey, Hem-light grey) with symplectic texture, Hem (N) (light grey) - nucleus. Thin section, without analyzer.

For instance, Dinovirus hoglandi (D.h.) virus-like structures, localized in sericite shale, have hexahedral cross-section shape, which presumably represents mineral pseudomorphoses of cross-sections of protein shells with icosahedral symmetry. They are in contact with microfossils of hexagonal cells, and together they are encapsulated in siliceous membranes formed during the replacement of the mucous film. The D.h. structures have formations similar to tails (Figures 5.1; 5.3), also encapsulated in siliceous membrane. The D.h.-1 structure consists of quartzhematite aggregate with symplectic texture of quartz and hematite, replacing prominent cell endoplasm (End) and ectoplasm (Ect). (Figure. 5.2.). In the central part of the D.h.-1 structure is a rounded nucleus-shaped formation, replaced with hematite and quartz, with a grain of apatite (AP) in between.

Dinovirus hoglandi virus-like structures may be microfossils of ancient eukaryotes, representatives of an extinct family of single-celled facultative parasites, or ancestors of giant viruses of the Mimiviridae family.

\section{Microfossils of the multicellular microorganisms in the sericite slate}

Structures that can be interpreted as microfossils of multicellular microorganisms (MMM) are present in microquartzites and sericite shales. They look like linearly elongated shapes of $1 \times 4 \mathrm{~mm}$ in size, formed by four cells (Figure. 6.1.). Together with flagella (Fl) they are surrounded by a common siliceous membrane, which was formed, apparently, during the silicification of the mucous biofilm. Microquartzites globules (Gl) are present in the sericite shale together with the MMM. The internal parts of the MMM consist of quartz-hematite aggregate with symplectic texture (Figure. 6.1-6.3). Formations similar to digestive vacuoles replaced with by Hem (DV) are found between the mineralized cytoplasm and the siliceous membrane. Inside the contours of one of the of the MMM "cells", you can see a rounded nucleus-like $(\mathrm{N})$ formation of $150 \times 250$ micrometers 


\section{International Journal of Paleobiology \& Paleontology}

in size, composed of hematite (Figure 6.1). The nucleus is surrounded by well- defined formations resembling cell endoplasm (End) and ectoplasm (Ect), replaced with quartz- hematite aggregate with symplectic texture (Figures 6.2; 6.3).

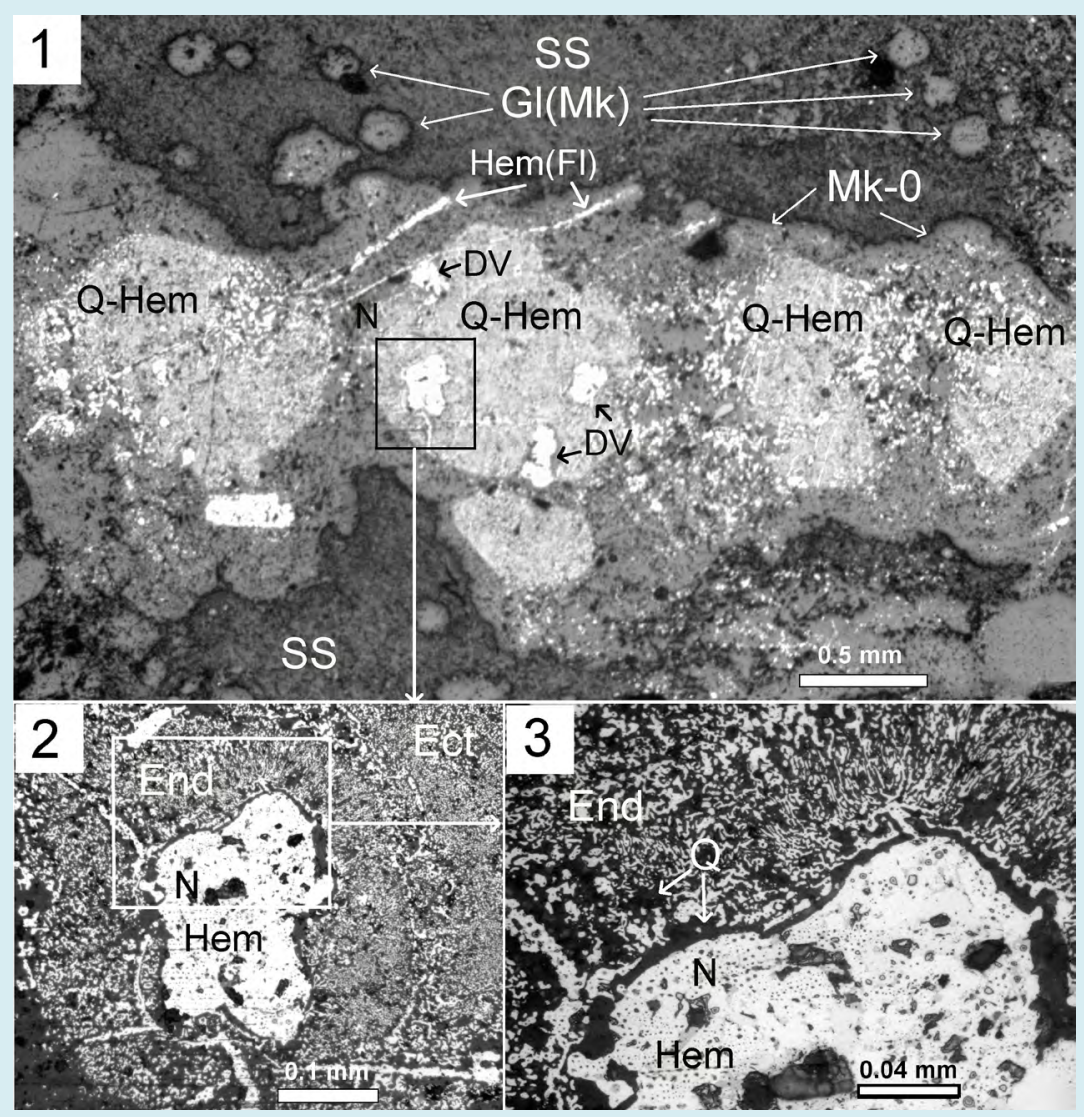

Figure 6: Microfossils of the multicellular microorganisms in the sericite slate. Thin section, reflected light, with analyzer. 6.1. Microfossils of multicellular microorganisms (MMM) with whip-like offshoot surrounded by microquartzites (Mk-0); 6.2. Nucleus of MMM (N) replaced with Hem (light grey), and fragments of endoplasm En and ectoplasm Ect replaced with quartzhematite aggregate with symplectic texture (Q-dark grey, Hem-light grey); 6.3. Fragment of MMM Nucleus (N) replaced with Hem (light grey), and fragments of endoplasm En - (Q-dark grey, Hem-light grey) replaced with quartz-hematite aggregate (Q-dark grey, Hem-light grey) with symplectic texture.

\section{Mineral Residue of Nucleoside Phosphates}

The mineralized cytoplasm and nuclei of some eukaryotic microfossils contain grains of apatite that could have been formed during fossilization from phosphoric acid residue of decayed ATP, RNA, and DNA nucleotides. During the silification of biofilms at temperatures above one hundred degrees Celsius, the organic matter of planktonic microorganisms - protoplasm, shells and membranes - decomposed into water, carbon and nitrogen oxides, which passed into the gas phase and were removed from the fossilization zone, being replaced by silica. During the decay of ATP, RNA, and DNA nucleoside phosphates, the contained phosphate residue remained near the site of silicification (within the volume of microfossils) in the form of phosphate ions, and bound to the calcium ion, forming apatite. Crystallization of apatite requires the mineral-forming medium to be supersaturated with phosphate and calcium ions in a local volume. Therefore, if the crystallization of apatite used phosphorus released during the decay of nucleoside phosphates, then knowing the size of apatite grains located in the nuclei and mineralized cytoplasm of eukaryotic microfossils, we can solve the inverse problem and, for the first time, approximate the mass of the primary source of phosphorus, i.e. the ancient nucleoside phosphates of ATP, RNA and DNA [1]. In modern eukaryotes $18.5 \%$ of phosphorus is contained in ATP, which, 


\section{International Journal of Paleobiology \& Paleontology}

on average, is $0.04 \%$ of the raw cell mass, and nucleic acid molecules contain about $10 \%$ of phosphorus. The fact that the structure of nucleoside phosphates is the same in all living beings of different kingdoms suggests that ancient organisms had the same composition of ATP, RNA, and DNA molecules and the content of phosphorus in them.

\section{Apatite in the Mineralized Cytoplasm and Nuclei of Some Eukaryotic Microfossils}

Apatite grains were identified in the mineralized cytoplasm and nuclei of eukaryotic microfossils, apparently formed from phosphoric acid residue of decayed ATP, RNA, and DNA nucleotides. For instance, an apatite grain was found in the mineralized cytoplasm (in the quartzhematite aggregate) of PY flagellate microfossil using scanning electron microscope JSM-6510LA with energydispersion spectrometer JED-2200 (Figure. 3.1.). Knowing the apatite density of $3.2 \mathrm{~g} / \mathrm{cm}^{3}$, its mass was estimated to be approximately 335100 picograms (pg) (1 pg - 10-12 g). Apatite contains $19 \%$ of phosphorus, and, therefore, this grain can contain about 64000 pg of phosphorus. It could be the residue of nucleoside phosphates of ATP, DNA and RNA released in the local volume during the fossilization of the cell. But in modern eukaryotes, ATP is contained in the cytoplasm of cells, and RNA and DNA are enclosed in the nuclei. If we assume that in the ancient eukaryotes the content of nucleoside phosphates in the nuclei and in the cytoplasm of cells was similar to the modern ones, it is possible to estimate what portion of the phosphorus in the mineralized cytoplasm PY could belong to ATF, and what portion belonged to DNA and RNA of the nucleus.

Protoflagellates yukhalina most likely had the shape of a flattened ellipsoid. Its volume, calculated using equation $\mathrm{V}=4 / 3 \pi \mathrm{abc}$, is $376991000 \mu^{3}$. The density of the cytoplasm of cells is slightly more than the density of water $\left(1 \mathrm{~g} / \mathrm{cm}^{3}\right)$, and the mass of $1 \mu \mathrm{m}^{3}$ of water is 1 picogram (pg). Therefore, the raw mass of PY could be about $376991000 \mathrm{pg}$. Assuming that the ancient ATF contained $18.5 \%$ phosphorus and constituted $0.04 \%$ of the raw cell mass, the Protoflagellates could contain $150800 \mathrm{pg}$ of ATP, containing, correspondingly, $28000 \mathrm{pg}$ of phosphorus. However, the mass of phosphorus in the apatite grain is much larger, about $64000 \mathrm{pg}$ and, consequently, the remaining $35670 \mathrm{pg}$, could previously be part of the nucleus genome. A DNA molecule weighing 1 pg contains about 1 billion pairs of nucleotides. Thus, the genome of the PY nucleus could contain 35670 billion pairs of nucleotides.

The apatite grain in the "nucleus" of the virus-like eukaryote Dinovirus hoglandi - D.h-1 is approximately $30 \times 30 \times 6 \mu \mathrm{m}$ in size, with a volume of $5400 \mu \mathrm{m}^{3}$, and contains
3200 pg of phosphorus. However, this phosphorus could originate not only from the RNA and DNA of the decayed genome, but also from the ATP nucleoside phosphate. If we assume that the "head" of the D. h-1 structure had icosahedral symmetry, then the volume of its cytoplasm was approximately 16 million $\mu \mathrm{m}^{3}$ (excluding 1 million $\mu \mathrm{m} 3$ of the "nucleus" volume), with a mass of about 16 million pg. At ATP concentration of $0.04 \%$ of the raw cell mass, the cytoplasm of the virus cell could contain $1184 \mathrm{pg}$ of phosphorus contained in this nucleoside phosphate. But the apatite grain contains 3200 pg of phosphorus, and, therefore, the remaining 2020 pg could belong to the DNA and RNA of the cell genome. Thus, if apatite crystallized from phosphoric acid residue of the decayed DNA and RNA genome containing about $10 \%$ of phosphorus, then the mass of the latter could be $20200 \mathrm{pg}$, and it could contain about 20200 billion of base pairs.

The apatite grain in hexagon-cell structure $(\mathrm{H}-2)$ with visible dimensions of $13 \times 25 \mu \mathrm{m}$ is most likely a longitudinal section of a hexagonal prism crystal (Figure 5.3). It should be taken into account that the observed cross-section of the crystal is a special case and the actual apatite grain size may be even larger. The estimated volume of the apatite grain could be about $10000 \mu \mathrm{m}^{3}$, with a mass of $32000 \mathrm{pg}$, containing $6080 \mathrm{pg}$ of phosphorus, respectively. The source of this phosphorus could be both decayed nucleoside phosphates of ATP, and DNA/RNA of the genome. We need to know the volume of the $\mathrm{H}-2$ cell to estimate how much phosphorus was contributed by ATP and the genome containing DNA and RNA. If the hexahedral contour of the $\mathrm{H}-2$ cell is a crosssection of an icosahedron, then its volume would be about 60 million $\mu \mathrm{m}^{3}$, with a mass of 60 million pg. With an ATP content of $0.04 \mathrm{wt} \%$, its mass would be $24000 \mathrm{pg}$, containing $4500 \mathrm{pg}$ of phosphorus. However, the apatite grain contains $6080 \mathrm{pg}$ of phosphorus, and, therefore, the remaining 1580 pg could belong to the DNA and RNA of the cell genome. If during apatite crystallization it contained phosphorus from phosphoric acid residue of decayed DNA and RNA with phosphorus content about $10 \%$, the genome mass could be $15800 \mathrm{pg}$, or about $15800 \mathrm{~Gb}$ ( $1 \mathrm{~Gb}-1$ billion base pairs).

Even considering significant errors in calculating the volume of cells and apatite grains, the genomes of Protoflagellates (PY), virus-like structure D.h.-1, and hexagon-cell structure $\mathrm{H}-1$ seem to be prohibitively large. For comparison, the human genome contains 3.2 billion $(\mathrm{Gb})$ base pairs, and the largest known genome of a living organism is the genome of Amoeba dubia $\mathrm{C}=670 \mathrm{~Gb}$ (200 times larger than the human genome). Additionally, according to some researchers, eukaryotic genomes increased and became more complex during evolution due to lateral transgenic transfer by viruses [3]. However, the size of eukaryotic genomes can be estimated in another independent way. 


\section{International Journal of Paleobiology \& Paleontology}

\section{Principle of Genomic-Nuclear Proportionality}

According to the model of skeletal DNA [12], the volume of modern eukaryotic nuclei is determined by the mass of DNA and RNA contained in the nucleus: the larger the size (molecular weight) of the genome, the larger the size of the nucleus it requires. That is, knowing the volume of the nucleus $\mathrm{V}^{\mathrm{N}}$ of eukaryotic microfossils, we can solve the inverse problem and indirectly determine the value (mass) genome $\mathrm{C}$ using the equation: $\mathrm{C}=\mathrm{V}^{\mathrm{N}} / \mathrm{Kc}$, where $\mathrm{Kc}$ is the proportionality coefficient. If we assume that the proportionality of the relationship between the volume of the nucleus and the size of the genome is inherited by single-cell eukaryotes from the earliest stages of their evolution, the proportionality coefficient can be calculated from the ratio of the volume of nuclei and the mass of the genomes of modern single- cell eukaryotes. For example, according to the literature data, for eukaryotes with different genome weights: Amoeba proteus ( $\mathrm{C}=290 \mathrm{pg}$ ), Amoeba dubia ( $\mathrm{C}=680 \mathrm{pg}$ ) and Saccharomyces cerevisiae yeast $(\mathrm{C}=1.2 \mathrm{pg}$ ), the coefficient of proportionality $\mathrm{Kc}\left(\mathrm{V}^{\mathrm{N}} / \mathrm{C}\right.$ ratio $)$ is on average about 50 .

If we use the principle of genomic-nuclear proportionality to estimate the size of the PY protoflagellate genome, the mass of the PY genome would be $42000 \mathrm{pg}$ for a core volume $\mathrm{V}^{\mathrm{N}}$ of about $2120000 \mu \mathrm{m} 3$ (at $\mathrm{Kc}=50$ ), which is very close to the value of $35670 \mathrm{pg}$ calculated from the apatite grain size. Thus, the masses of the PY nucleus genomes estimated by different independent methods are quite comparable.

The genome masses of foraminifera-like structures (Fo), estimated both by the included apatite grains and by the size of the nuclei, also amounted to tens of thousands of picograms. Thus, the mass of the foraminifera-like structures Fo-2 genome calculated from the apatite grain (Figure 3.1; 3.3) was $83440 \mathrm{pg}$, and the mass genome calculated from the size of the unclear nucleus $\mathrm{C}=83800 \mathrm{pg}$. The genome masses of foraminifera-like structures Fo-4 was 52000 pg (Figure 3.2), and for foraminifera Fo-3 it was $35400 \mathrm{pg}$ (Figure 3.1).

The mass of D.h.-1 genome estimated using the principle of genomic-nuclear proportionality, for a nucleus volume of $1000000 \mu^{3}$, at $\mathrm{Kc}=50$, would be $20000 \mathrm{pg}$, or 20000 billion of base pairs, which is almost the same as the value of 20200 $\mathrm{Gb}$ obtained from apatite- based calculations.

A formation resembling the nucleus $(\mathrm{N})$, composed of hematite, inside the contours of one of the MMM "cells" (Figures 6.1-6.3) has dimensions of $150 \times 250 \mu \mathrm{m}$, and possibly a very significant mass of the genome. However, the symmetrical shape of the formation suggests that the size of the nucleus in the cell is the result of division that began at the time of fossilization of the MMM.

\section{Discussion}

The masses of the genomes of eukaryotic microfossils: flagellates, amoeboid and virus-like structures, foraminifera, and multicellular microorganisms, estimated both by the included apatite grains and by the size of the nuclei, averaged tens of thousands of picograms and, accordingly, tens of thousands of billions of nucleotide pairs. At the same time, the mass of eukaryotic genomes may be even greater, even with significant errors, when estimating the size of apatite grains, volumes, and cell nuclei. First, the true size of apatite grains may be larger than the size estimated from the observed crystal cross-sections, and, secondly, in the mineral-forming medium (limited by the cell volume), there may be a certain amount of dispersed phosphorus, remaining after the end of crystallization of the mineral.

In modern eukaryotes with large genomes, a significant part of the nucleotide sequences is not transcribed at all and is called silent DNA. For example, non-coding parts of genes in the human genome with a mass of about $3 \mathrm{pg}$ (three billion pairs of nucleotides) make up $97 \%$ of the genome mass. According to the model of Minkevich and Patrushev [13], non-coding sequences of eukaryotic genomes perform a protective (reserve) function against the nucleotides of the coding part damaged by mutagens. Therefore, the huge genomes of ancient eukaryotes most likely also contained mostly non-coding sequences of genes that could play the role of a reserve protecting the vital activity of cells from the impact of the flow of mutagens from the environment. One of the mutagenic factors was the high background radioactivity of the environment caused by high concentrations of the radioactive isotope ${ }^{40} \mathrm{~K}$, both in seawater and inside the cells of microorganisms [1,2].

Favorable ecological and geochemical conditions and abundance of biophilic elements were necessary for the emergence and evolution of huge genomes of ancient eukaryotes of planktonic microorganisms. The chemical composition of marine waters in the Paleoproterozoic, as in modern seas and oceans, was characterized by low concentrations of potassium and phosphorus, which limit the quantitative and qualitative development of life. The content of phosphate ion in seawater is the main factor limiting the growth and reproduction of microorganisms [14-16]. Without phosphorus, the synthesis of nucleoside phosphates and proteins, and life in general, become impossible! In the Paleoproterozoic, phosphorus entered the water of marine basins mainly from tholeiitic, essentially sodium basalts widespread on the ocean floor, but in the continental highpotassium basalts of Hogland, the phosphorus content was more than three times higher [1,9]. Therefore, the water of the inland basin (Abel Sea) could have been significantly 


\section{International Journal of Paleobiology \& Paleontology}

enriched with phosphate ion during the Hoglandic time.

\section{Conclusion}

Apatite grains found in mineralized cytoplasm and nuclei of microfossils could have crystallized from phosphoric acid residue of decayed nucleotides. This made it possible to estimate for the first time the size of the genomes of ancient eukaryotes and virus-like structures, which turned out to be tens of thousands of times larger than the genomes of modern single-cell organisms. The masses of genomes of eukaryotic microfossils: flagellates, foraminifera, and viruslike structures, estimated both by the included apatite grains and by the size of the nuclei, calculated in accordance with the principle of genomic-nuclear proportionality, also turned out to be huge, and, on average, amounted to tens of thousands of picograms and, consequently, could contain tens of thousands of billions of nucleotide pairs.

Presumably, the giant genomes of ancient eukaryotes consisted predominantly of non- coding sequences that served as a reserve that ensures the vital activity of cells when exposed to streams of mutagens from the environment. One of the mutagenic factors could be significant radioactivity, both background and intracellular, caused by high concentrations of the radioactive isotope ${ }^{40} \mathrm{~K}$ in seawater $[1,2]$. The favorable ecological and geochemical environment that existed in the Paleoproterozoic under the conditions of underwater eruption of high-potassium rocks, and the abundance of biophilic elements (especially phosphates) in the waters of the continental basin, could play the role of an evolutionary springboard in the history of the biosphere evolution.

The research materials are important for improvement of the paleontological record, but they also allow us to expand the knowledge base and ideas about the formation and evolution of eukaryotic genomes, whose masses, in proportion to the size of the nuclei, could decrease in the course of evolution, while some of the transcribed nucleotide sequences increased.

\section{Acknowledgement}

We would like to thank my colleagues for technical support: Prof. Krivovichev V.G., Prof. Prasolov E.M., Dr. Galankina O.L., MSc. Putinseva L.V., MSc. Kobilkov S.V. and his colleagues. In addition, a thank you to Alexander Alexandrov of Ardis Translation, who kindly proofread the English version of this paper.

\section{References}

1. Belyaev AM (2018) Paleoproterozoic Underwater Volcanism and Microfossil-Like Structures in the
Metasedimentary Siliceous Rocks (Hogland Island, Russia). Journal of Earth Science 29(6): 1431-1442.

2. Belyaev AM (2019) Prospects for studying microfossils in volcanogenic-sedimentary siliceous rocks of the Paleoproterozoic. Paleontological Institute RAS 2: 2843.

3. Canchaya C, Fournous G, Chibani Chennoufi S (2003) Phage as agents of lateral gene transfer. Curr Opin Microbiol 6(4): 417-424.

4. Westall F, Boni L, Guerzoni E (1995) The experimental silicification of microorganisms. J Paleontol 38(3): 495-528.

5. Benning LG, Phoenix V, Yee MJ (2002) Molecular characterization of cyanobacterial cells during silicification: A synchrotronbased infrared study. Geochem Earth Surf 6: 259-263.

6. Laidler JR, Stedman KM (2010) Virus silicification under simulated hot spring conditions. Astrobiology 10(6): 569-576.

7. Belyaev AM, Bogdanov YB, Levchenkov OA (1996) Bimodal volcanic formations of the Wiborg batholith on the Island of Hogland (Suursaari), Russia. In: Rapakivi Granites and Related Rocks: Correlation on a Global Scale (Abstr. Vol. IGCP-315 Symp.), Helsinki, Finland, pp: 5.

8. Belyaev AM, Bogdanov YB, Levchenkov OA (1998) Petrogenesis of the bimodal rapakivi- related volcanites of the Island of Hogland, 1.64 Ga Wiborg batholith, Russia. In: Rapakivi Granites and Related Rocks: Correlation on a Global Scale (Abstr. Vol. IGCP315 Symp.), Madison, USA, pp: 139-140.

9. Belyaev AM (2013) Petrology of volcanic rocks from the rapakivi formation (Island Hogland). J Regional Geology and Metallogeny 55: 28-36.

10. Pawlowski J, Holzmann M, Berney C (2003) The evolution of early Foraminifera. Proceedings of the National Academy of Science 100(20): 11494-11498.

11. Abergel Legendre M, Claverie JM (2015) The rapidly expanding universe of giant viruses: Mimivirus, Pandoravirus, Pithovirus and Mollivirus. FEMS Microbiol Rev 39(6): 779-796.

12. Cavalier Smith T (2005) Economy, speed and size matter: evolutionary forces driving nuclear genome miniaturization and expansion. Ann Bot 95(1): 147175. 


\section{International Journal of Paleobiology \& Paleontology}

13. Minkevich GI, Patrushev LI (2007) Genomic noncoding sequences and the size of eukaryotic cell nucleus as important factors of gene protection from chemical mutagens. Russian Journal of Bioorganic Chemistry 33(4): 439-442.

14. Delaney ML (1998) Phosphorus accumulation in marine sediments and the oceanic phosphorus cycle.
Global Biogeochemical Cycles 12(4): 563-572.

15. Paytan A, McLaughlin K (2007) The Oceanic phosphorus cycle. Chemical Reviews 107(2): 563-576.

16. Julia Diaz, Ellery Ingall, Claudia Benitez Nelson (2008) Marine Polyphosphate: A Key Player in Geologic Phosphorus Sequestration. Science 320(5876): 652655. 